\title{
TIG 法によるアルミニゥムと軟鋼の接合についての検討*
}

\author{
杉山襀应** \\ Some Experiments on Joining Aluminum to Mild Steel \\ by TIG Welding*
}

By Yoshihiko Sugiyama**

\begin{abstract}
This report deals with some experiments on TIG welding aluminum and its alloys to mild steel coated with various materials including $\mathrm{Al}, \mathrm{Al}-\mathrm{Si}, \mathrm{Al}-\mathrm{Cu}, \mathrm{Al}-\mathrm{Be}, \mathrm{Sn}, \mathrm{Zn}, \mathrm{Zn}-\mathrm{Al}$ and so on by a simple hot dipping method.

The results obtained in this study are summarized as follows.

1) Additions of $\mathrm{Si}, \mathrm{Be}$ and $\mathrm{Cu}$ to $\mathrm{Al}$ inhibited the formations of an intermetallic layer between mild steel and $\mathrm{Al}$-base coating, but additions of $\mathrm{Mg}$ and $\mathrm{Ag}$ did not, and in the cases of $\mathrm{Zn}$ and $\mathrm{Zn}$-Al coatings an intermetallic layer was little observed.

2) The tensile strengths of welded joints were equal to or higher than those of aluminum parent alloys in 1100 and 3003 alloys, but lower than in 5052, 5083 and 6061 alloys.

3) As tensile testing of heat-treated welds showed reduction of strength, these joints are not applicable to high temperature services. But there is possibility for use of aluminum alloys are concerned.

4) The definite relation between coating materials and mechanical properties of welded joints was not observed as far as this study was concerned. But further study should be necessary for explaining this relation, using test panels which have high quality coating on the steel.

5) As a whole a 4043 filler rod was satisfactory comparing with a 5356 filler rod.

It has been confirmed from this study that aluminum can be joined to mild steel by TIG weld. ing provided mild steel is suitably coated with proper materials. Mechanical properties of welded joints, however, depend mainly on the coating quality and skill for welding technique. Therefore, under the conditions of satisfactory coating quality and skillful welding technique, further study should be necessary especially regarding the relation between mechanical properties of weld and an intermetallic layer with metallurgical consideration of interfacial layers of various coating combinations.
\end{abstract}

\section{1.はじめに}

アルミニウムの需亚が増すにしたがって，アルミニウ ムと鋼あるいは銅などの異種金属との信頼すべき接合法 を確立する必要が生じでさいる。しかしアルミニウム はこれらの金属と溶融し合うと，世゙い弱な金履間化合物 を形成するために，たとえば正接やろう付けのごとく， 母材を溶融せしめないで接合する方法を除いては，通常 の溶接法によって直接に溶融溶接しても良好な継手が得 ら机ない，てのため溶接に先立ちアルミニウムと接合す る異種金属に対して，アルミニウム上溶融し合って屯， 悪影響を及代さないような材料を被稪するごよき，特別 な炕理が必恶とされる。この種の接合法はこれまでにも 研覀されていて， Miller 书よび Mason'はアルミニウ

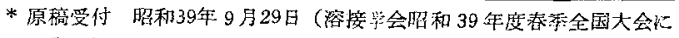
て発婊)

*** 正具 住友㪕金属工業KK研究部 Member, Research Department, Sumitomo Light Metal Industries Ltd.
ムを被稪したステンレス鎆管とアルミニウム合金管との TIG 溶接法について報告して拈り，末たCook 捄よび Stavish $^{2)}$ は銅に BAg-3 銀ろうを被覆して，銅とアル ミニウムを MIG 溶接した結果を報告している．さらに

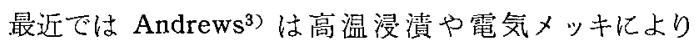
$\mathrm{Sn}, \mathrm{Al}$ および $\mathrm{Zn}$ などを被稪した軟鋿とアルミニウム 合金とを TIG 溶接する方法について組織的な研究を行 なっている、しかしながらわが国では，との種の溶接法 に関する報告がなく，また被徱材そのものについてむ。 まだ検討すべき点があるように思われるので，本実験で はアルミニウムおよびその合金と軟鎙との接合におい て，各種の被復材を軟鍮側に施こし，TIGにて溶接す る方法を検討した．被覆の方法には高温浸漬，クラッド 法, 電気メッキ，溶射あるいは化学反応によるむのなど の多くの方法ひがあるが，本実験ではすっとも簡単に行 なえると思水れる高温浸清法によった。 
な执本来ならば，乙の種の接合法をブレイズ溶接とい うべきであるうが，本報告では単に溶接なる言染を用い た.

\section{2. 供試材料および実験方法の概略}

まず予備実駼において，高温浸漬によって Al を被稪 した市販軟鎝板と 1100 板（工業用純アルミ）とを TIG にて4043溶加材により突合せ溶接し，溶接部の顕微鏡観 祭加ら溶接の可能性を検討した。 その結果, 溶接の可能 性のあることが認められたので, あらためて被㠅材とし て $\mathrm{Al}, \mathrm{Al}$ にそれぞれ $\mathrm{Si}, \mathrm{Mg}, \mathrm{Cu}, \mathrm{Ag}, \mathrm{Be}, \mathrm{Mg}-\mathrm{Si}$ を 含んだ $\mathrm{Al}$ 基合金の他，Zn，Zn-Al 拈よび $\mathrm{Sn}$ を選ん で,これらを高温浸漬によって軟鋼板に被覆し，適当と 思われる被覆材とともに抢よこの浸漬条件を選定した。

そして参考のためにそれぞれの被覆と軟鐥との境界に生 じた合金層のかたさ分布をマイクロビッカースによって 調べた。な被覆に際しては，浸漬前に軟鋼板の予熱な どの前処理を行なわず，単に軟鋼板表面の酸化皮膜をグ ラインダで除去した後に，ワイヤブラシがけしたのみ で，ただちに溶湯中に浸漬し，上くに酸化防止のための フラックスを用いなかった。

つぎに各種の材料で被覆した板厚 $3.2 \mathrm{~mm}$ の軟鋼板上 3003-H 16 合金板之を，開先形状をエ形および片面グル ーブ（軟鋼側に $40^{\circ}$ ) の二種類に，層数を $1 \sim 2$ 層にそ れぞ扎変え, Table 1 に示した条件で 4043 溶加材によ り突合せ溶接した。さらに同じく板厚 $3.2 \mathrm{~mm}$ の各種ア ルミニウム合金板を，被覆材を異にする軟鋼板と4043お

Table 1 Welding condition

\begin{tabular}{l|c|c|c|c|c}
\hline Joint design & $\begin{array}{c}\text { Pass } \\
\text { no. }\end{array}$ & $\begin{array}{c}\text { Weld, } \\
\text { current, } \\
\text { A }\end{array}$ & $\begin{array}{c}\text { Argon } \\
\text { fow, } \\
\text { lpm }\end{array}$ & $\begin{array}{c}\text { Elect. } \\
\text { dia., } \\
\text { mm }\end{array}$ & $\begin{array}{c}\text { Filler } \\
\text { dia., } \\
\text { mm }\end{array}$ \\
\hline $\begin{array}{l}\text { Square or } \\
\text { single bevel }\end{array}$ & $1-2$ & $180 \sim 220$ & 8 & 3.2 & 2.4 \\
\hline
\end{tabular}

よび5356溶加材により溶接した。このようにして得られ た溶接パネルから引張試験片を採取して，継手の機栈的 性質を求め, 継手の機械的性質に及代す被覆材, 溶加 材, 開先わよび溶接層数などの影響を調べた、また一部 の試料については長時間加熱による溶接部の機械的性質 の変化を調べた。

その他，本溶接法をアルミニウム管と軟鋼管の乫合せ 溶接に適用してみた。

板材の突合せ溶接に用いた軟鋼板ならびに板あるいは 管材の溶接に用いた溶加材（1260溶加材は管材の溶接の みに使用）の化学組成を Table 2 および 3 亿ままた 材の機械的性質を Table 4 にそ机ぞれ示す.
Table 2 Chemical composition of mild steel

\begin{tabular}{c|c|c|c|c|c}
\hline \multicolumn{6}{c}{ Chemical composition, \% } \\
\hline $\mathrm{C}$ & $\mathrm{Si}$ & $\mathrm{Mn}$ & $\mathrm{P}$ & $\mathrm{S}$ & $\mathrm{Cr}$ \\
\hline 0.03 & $<0.005$ & 0.28 & 0.027 & 0.014 & 0.01 \\
\hline
\end{tabular}

Table 3 Chemical compositions of filler rods

\begin{tabular}{|c|c|c|c|c|c|c|c|c|c|}
\hline \multirow{2}{*}{$\begin{array}{l}\text { Filler } \\
\text { rod }\end{array}$} & \multicolumn{9}{|c|}{ Chemical composition, $\%$} \\
\hline & $\mathrm{Cu}$ & $\mathrm{Fe}$ & $\mathrm{Si}$ & $\mathrm{Mn}$ & $\mathrm{Mg}$ & $Z_{n}$ & $\mathrm{Cr}$ & $\mathrm{T} \mathbf{i}$ & Al \\
\hline 404 & 0.00 & 0.23 & 5. 14 & 0,02 & $<0.01$ & 0.0 & $<0.0$ & $\mid<0.01$ & ren \\
\hline 5356 & 0.00 & 0.21 & 0.15 & 0.03 & 5.06 & 0.01 & 0.15 & 0.16 & ret \\
\hline 1260 & 0.00 & 0.17 & 0.07 & 0.002 & $<0.01$ & $<0.01$ & $<0.01$ & $<0.01$ & rem. \\
\hline
\end{tabular}

Table 4 Mechanical properties of parent metals

\begin{tabular}{c|c|c|c}
\hline \hline Parent metal & $\begin{array}{c}\text { Tensile } \\
\text { strength, } \\
\text { kg/mm2 }\end{array}$ & $\begin{array}{c}\text { Yield strength } \\
\left(\begin{array}{c}0 \% \text { offset }), \\
\text { kg/m m } 2\end{array}\right.\end{array}$ & $\begin{array}{c}\text { Elongation, } \\
\%\end{array}$ \\
\hline Mild steeI & $\mathbf{4 4 . 7}$ & 33.4 & 38 \\
Commercial A1 & 15.7 & 13.6 & 12 \\
3003 & 18.3 & 17.4 & 8 \\
5052 & 14.8 & 12.9 & 15 \\
5083 & 30.2 & 28.4 & 7 \\
6061 & 44.7 & 40.6 & 7 \\
\hline
\end{tabular}

\section{3. 実 験 結 果}

\section{1 予備実験結果}

Photo. 1 の(1) 打よび（2）は鉿板をそ机ぞ机 $700^{\circ} \mathrm{C}$ および $680^{\circ} \mathrm{C} の \mathrm{Al}$ 溶湯中に, 10 分間执よび 1 時間浸漬した昐合の被覆層之鍋板の境界部の頙微鏡組織 を示したあのである，写真にみら机るように，境界から 鋼側に向って合金層が不規則に形成されている．との合 金層については種々の研究があり,たとえば Heumann ${ }^{53}$ らは $\mathrm{Fe}_{2} \mathrm{Al}_{5}$ に近い組成を有するととを示し，また Coburn $^{6)}$ はこの層には約 45\%の Fe が含まれ，Al-Fe の状態図に上れば，Fe 33.5\% および45\%のとてろでは， それぞれ $\mathrm{FeAl}_{3}$ および $\mathrm{Fe}_{2} \mathrm{Al}_{5}$ が形成される筈である が，この層は $\mathrm{FeAl}$ を主体に他传干の $\mathrm{Fe}_{3} \mathrm{Al}$ より成 っているとしている.いずれにしても，ての合金層が溶 接によってどのように変化し，また溶接部の諸性質にい かなる影響を及ばすかについては興味がある。同じく Photo. 1 の（3）蛙（2）示した Al を被覆した鋼 板を1100材とI形開先で, 4043 溶加材を用いて TIG 溶 接した埸合の, 溶接金属上鋼板の境界部の顕微鏡組織で ある・写真によれば, 被覆操作の際に形成された合金層 は溶接によってほとんに゙成長せず，また被覆層は溶加材 と融合して溶接金属を形成しており，接合状態もまず良 好であるとみなされる。

以上の結果から, 鋼倒に $\mathrm{Al}$ 被覆を行なえば, 溶接が できる見通しが得られたが, Al 被覆と鋼の境界に生ず る合金層はぜい弱であり，その厚さが增すにしたがって 


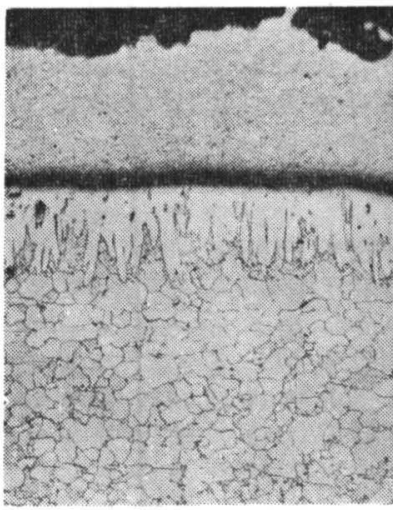

(1) As hot-dip coated with $\mathrm{Al}\left(700^{\circ} \mathrm{C} \times 10 \mathrm{~min}\right.$.
(2) As hot-dip coated with Al $\left(680^{\circ} \mathrm{C} \times 1 \mathrm{hr}\right.$. $)$

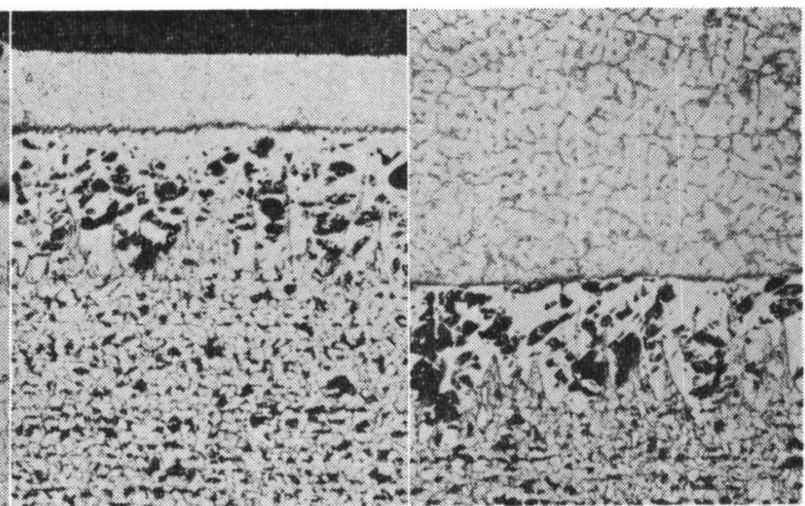

(3) Weld between Al-coated steel (2) and comm. pure Al made with 4043 filler rod

Photo. 1 Photomicrographs showing possibility of welding aluminum to coated mild steel $(\times 100) \times 4 / 5$

被覆の延性が阻害されることが明らかにされており したがってあまり合金層が厚い場合には，溶接継手に悪 影㗽を及ばすおそれがあるので，被覆材について若干検 討を加えた。

\section{2 被覆材について}

鋼板に Al を被覆する方法あるいは被覆された鋼板の 諸性質については, aluminised steel に関連して多く の研究報告があり, 高温浸漬法による $\mathrm{Al}$ 被覆に関して む, 単に $\mathrm{Al}$ 浴に鋼板を浸漬するのみでは, 上述のよう に境界に大きな合金層が形成されるので，この合金層の 形成を抑制するために種々の方法がとられている。乙れ らの中には，たとえば浸漬温度や時間に関して合金層の 成長を抑制するような浸漬条件にもってゆくように，条 件そのものを管理する方法や，あるいは $\mathrm{Al}-\mathrm{Fe}$ 間の拡 散を抑制するような元素を Al に添加する方法があり， 後者の場合 $\mathrm{Si}$ 添加がよく知られ4), その他 $\mathrm{Be} や \mathrm{Ti}$ などあ効果があるといわれている8). 本実験では後者の 方法に着目し，また $\mathrm{Al}$ 以外の金属で鋼を被覆する力法 む考えられるので, $\mathrm{Al}$ および $\mathrm{Al}$ 基合金の被覆の他に， $\mathrm{Zn}, \mathrm{Zn}-5 \% \mathrm{Al}$ および $\mathrm{Sn}$ の被覆を試みた。これらの材 料はいずれも溶融温度が異なるため, 当然浸漬条件も異 なり, 適当な条件を求めるためにはかなりの実験を要す るので, 本実験では各被覆材について 3 段階程度の温度 を選び, 浸漬時間を適宜に変えて, 主として被覆の容易 さおよび各条件で顕微鏡にて測定した合金層と被覆層の 厚さから, 被覆材を選定するとともに, およその実験室 的な浸漬条件を求めた. このようにして得られた各種の 被覆と軟鋼板との境界部の一例を Photo. 2 に, また試 験片の作成に適用した浸漬条件を Table 5 にそれぞれ
Table 5 Coating condition in hot-dipping

\begin{tabular}{c|c|c}
\hline \hline Coating material & Temperature, ${ }^{\circ} \mathrm{C}$ & Time, min \\
\hline $99.99 \% \mathrm{Al}$ & $700 \sim 720$ & 5 \\
$\mathrm{Al}-4.4 \% \mathrm{Cu}$ & $700 \sim 720$ & 5 \\
$\mathrm{~A} 1-0.6 \% \mathrm{Be}$ & $720 \sim 750$ & 5 \\
$\mathrm{Al}-12 \% \mathrm{Si}$ & $750 \sim 780$ & 10 \\
$\mathrm{Zn}$ & 480 & 25 \\
$\mathrm{Zn}-5 \% \mathrm{Al}$ & $750 \sim 780$ & $5 \sim 10$ sec. \\
\hline
\end{tabular}

Table 6 Hardness distributions of interface region between steel and coating

\begin{tabular}{l|c|c|c}
\hline \multirow{2}{*}{$\begin{array}{l}\text { Coating } \\
\text { material }\end{array}$} & \multicolumn{3}{|c}{ Hardness distributions (Micro-Hv) } \\
\cline { 2 - 4 } & Coating & $\begin{array}{c}\text { Interface } \\
\text { region }\end{array}$ & Steel \\
\hline $99.99 \% \mathrm{Al}$ & $33.3,36.3,36.5$ & 498,606 & 134,135 \\
$\mathrm{~A} 1-12 \% \mathrm{Si}$ & $74.8,80.2,75.7$ & 468,592 & 141,159 \\
$\mathrm{~A} 1-4.4 \% \mathrm{Cu}$ & 101,110 & 707,238 & $158,156,157$ \\
$\mathrm{~A} 1-2.5 \% \mathrm{Mg}$ & $67.8,72.4,40.5$ & 634,493 & 138,148 \\
$\mathrm{Al}-\mathrm{Ag}$ & $47.6,42.1,44.7$ & 538,753 & 154,133 \\
\hline
\end{tabular}

示す. Photo. 2 に示した試料はそれぞれ浸漬温度およ び時間を異にするものが含まれているので，明確な判断 を与え難いが，写真からそれぞれ $\mathrm{Si}, \mathrm{Be}$ および $\mathrm{Cu}$ を $\mathrm{Al}$ に加えた被覆材では，単に $\mathrm{Al}$ のみを被覆したもの (Photo. 1) に比へて, 合金層の形成が抑制され， $\mathrm{Al}$ に $\mathrm{Mg}$ および Agをそれぞれ添加したものは効果のない ことがわかる，また $\mathrm{Zn}$ および $\mathrm{Zn}-5 \% \mathrm{Al}$ を被覆した 場合には, $\mathrm{Zn}$ 被覆ではごく薄く合金層(鋼板を $\mathrm{Zn}$ 浴に 高温浸漬する場合には， $\zeta, \delta_{1}, \gamma$ なよ゙の $\mathrm{Fe}-\mathrm{Zn}$ 化合物 が形成される）が認められるが， $\mathrm{Zn}-5 \% \mathrm{Al}$ 被覆では合 金層がほとんど認められない.なお $\mathrm{Sn}$ は実験室的な浸 漬条件では, 被覆がほとんど不可能であったので除外し た. 以上の結果から本実験における供試材の被覆には, 

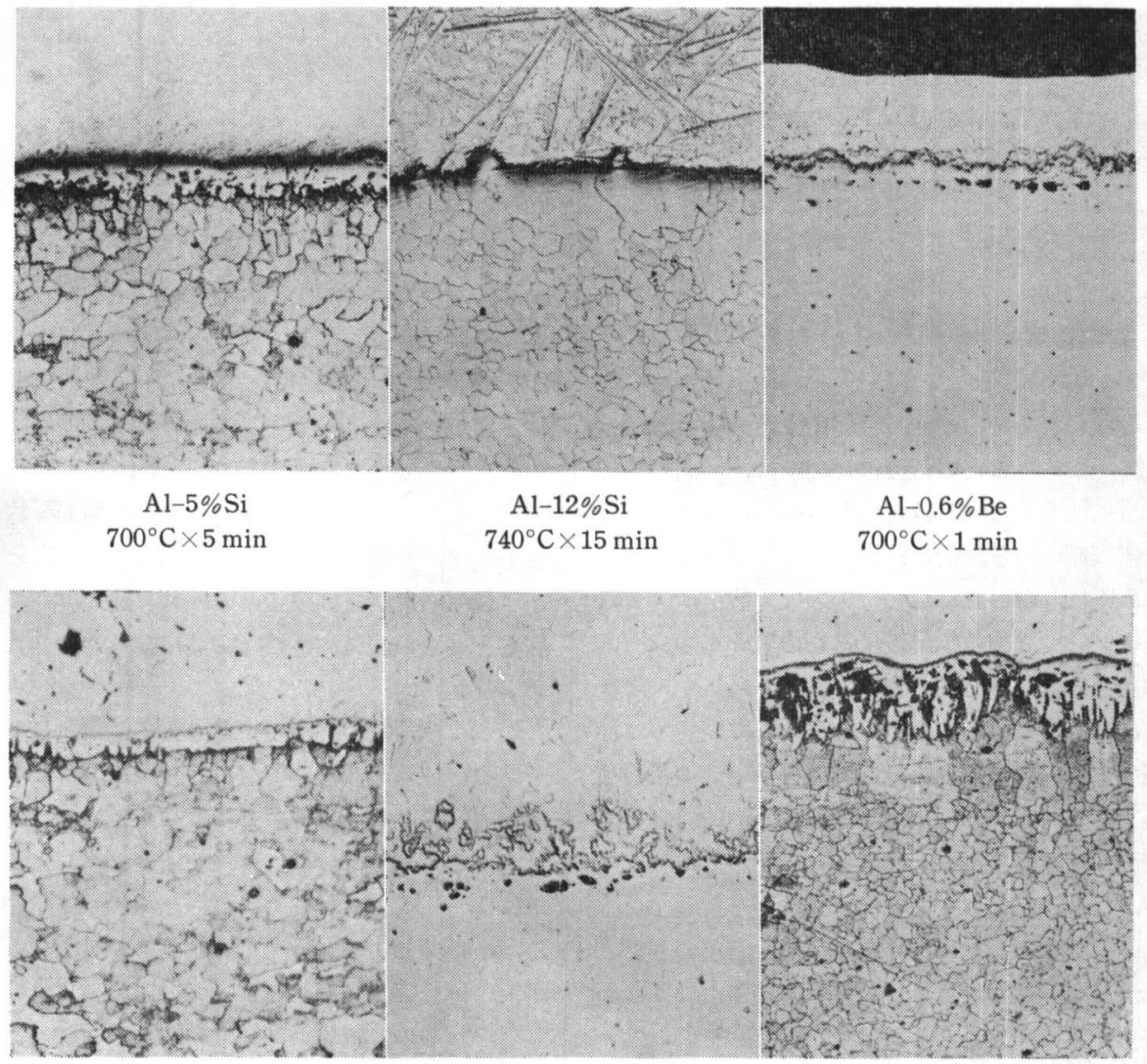

$\mathrm{Al}-4.4 \% \mathrm{Cu}$

$700^{\circ} \mathrm{C} \times 5 \mathrm{~min}$

$740^{\circ} \mathrm{C} \times 15 \mathrm{~min}$

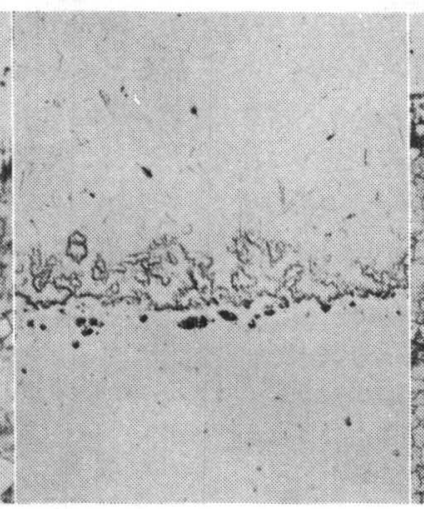

$\mathrm{Al}-1 \% \mathrm{Mg}-0.6 \% \mathrm{Si}$ $700^{\circ} \mathrm{C} \times 3 \mathrm{~min}$

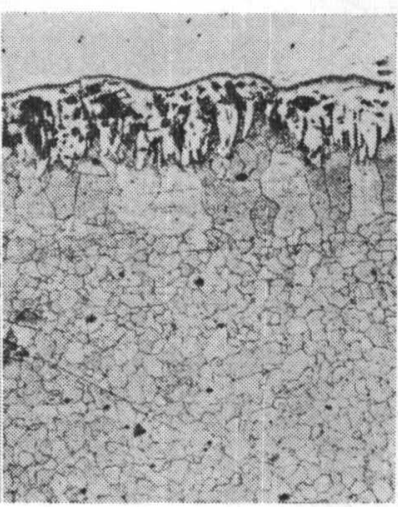

$\mathrm{Al}-2.5 \% \mathrm{Mg}$

$670^{\circ} \mathrm{C} \times 5 \mathrm{~min}$

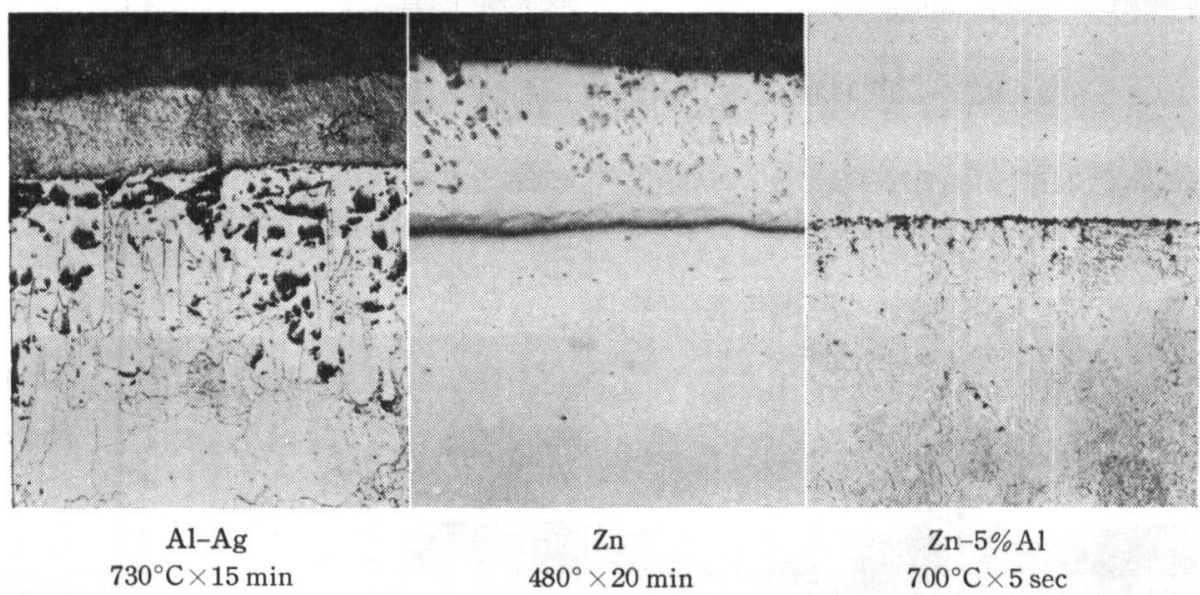

Photo. 2 Photomicrographs of the interface regions between mid steels and various coating materials

$(\times 100) \times 4 / 5$ 
$\mathrm{Al}, \mathrm{Al}-\mathrm{Si}, \mathrm{Al}-\mathrm{Be}, \mathrm{Al}-\mathrm{Cu}, \mathrm{Zn}$ および $\mathrm{Zn}-\mathrm{Al}$ を用いる ととにした.

参考のために, 軟鋼板と被覆層との境界部のかたさ分 布をマイクロビッカースによって測定した結果の一例を Table 6 に示す. 表によれば $\mathrm{Al}-\mathrm{Fe}$ 合金層は非常にか たく，そして $\mathrm{Al}$ に Si および $\mathrm{Cu}$ を添加するととに よって形成が抑制された合金層む, 単に Al で被覆した 場合に生じた合金層のかたさ分布とあまり異ならないと とがわかる。

\section{3 溶接結果}

\section{3 .1 溶接施工}

一般に行なわれている同種金属相互の溶接と異なっ て,アルミニウムと鋼との溶接においては, 鋼側が溶融 しないように注意しなり机ばならないのはいうまであな いが，まず鋼側の被覆層をアークによって溶融はく離せ しめないようにしなければならないので, 溶接にはある 程度の熟練が必要である. 溶接は最初のアークスタート のときがもっとも重要であって, スタート時に一たん被 覆層が溶融はく離すると, その後の溶接を継続するとと は不可能である. 被覆層の溶融はく離の傾向は被覆の種 類によってあ異なるようで, $\mathrm{Zn}$ および $\mathrm{Zn}-5 \% \mathrm{Al}$ を被 覆したむのは比較的溶接が容易であったが，その他では とくに $\mathrm{Al}-\mathrm{Cu}, \mathrm{Al}-\mathrm{Be}$ および $\mathrm{Al}-\mathrm{Si}$ などを被覆したも のははく離しやすいようにみられた，また溶接の容易さ は開先形状によっても異なり, 突合せ溶接においては, I 形よりも鋼側に開先をとったほうが溶接しやい.

板厚 $3.2 \mathrm{~mm}$ の軟鋼板に $40^{\circ}$ の開先をとり, それぞれ $\mathrm{Al}$ および $\mathrm{Zn}$ を被覆した後に, 6061 合金板と4043溶加 材で突合せ溶接した場合の溶接部の外観と断面の一例を Photo. 3 に示した.

被覆層の厚さは溶接作業上からは $0.1 \mathrm{~mm}$ 程度は必要 であると思われる.

なお Andrews ${ }^{3)}$ は溶接中に母材裏側の被覆層が急速 に酸化し, このため溶融金属と被覆層のなじみが妨げら
れるとして，トーチ以外からも別にシールドガスによっ て, 溶接部を保護しているが, 本実験においては通常の 技法で溶接を行なった.

\section{3 .2 溶接部の機械的性質}

\section{(1) 板材の突合せ溶接部}

Table 7 は板厚 $3.2 \mathrm{~mm}$ の 3003-H 16 (引張強さ 18.3 $\left.\mathrm{kg} / \mathrm{mm}^{2}\right)$ 合金と同じく板厚 $3.2 \mathrm{~mm}$ の被覆材料を異に する軟鋼板とを, 開先形状および層数を変えて，4043溶 加材により突合せ溶接した場合の継手の機械的性質 (余 盛のまま) を示したものである。溶接部の引張強さはい ずれむ3003- O 材程度の值が得られたが, 引張試験にお ける切断個所はアルミニウム側母材および溶接金属と軟 鋼の境界部のいずれかであって, 後者は前者に比べて伸 びが少ない.すべての被覆材について開先形状および層 数を共通に変えていないので, 正しい評価を与え難い が, 表の結果からは被覆材の種類, 開先形状および溶接 層数と継手の機械的性質との間にはっきりした傾向が認 められない.

さらに溶接時の作業性を考虑して, 鋼側に $40^{\circ}$ の開先 をとり，各種の被覆材で被覆した後に，4043および5356 溶加材を用いて, 各種のアルミニウム合金と 1 層で突合 せ溶接し，溶接部の機械的性質を調べた．その結果を Fig. 1 3 亿示す. 図によれば結果にバラッキがみられ るが, 1100 おご3003合金のように，軟質材の引張強さ が低い材料では, 引張試験において母材で切断したもの あみられるのに対し，5052，5083および6061合金では， 母材で切断した試験片はまったくなく, 全体を通じて引 張強さの最高值は， $\mathrm{Al}-4.4 \% \mathrm{Cu}$ を被覆した軟鋼板と 5083 合金を4043溶加材で溶接した場合の $17.0 \mathrm{~kg} / \mathrm{mm}^{2}$ であった. 被晋材の種類には溶接部の機械的性質に関し て明らかな差異は認められず, 溶加材の種類について は，全体として，5356溶加材より4043溶加材による溶接 部のほうが概して結果がよいようである.

試験後の引張試験片の一例を Photo. 4 亿示す.

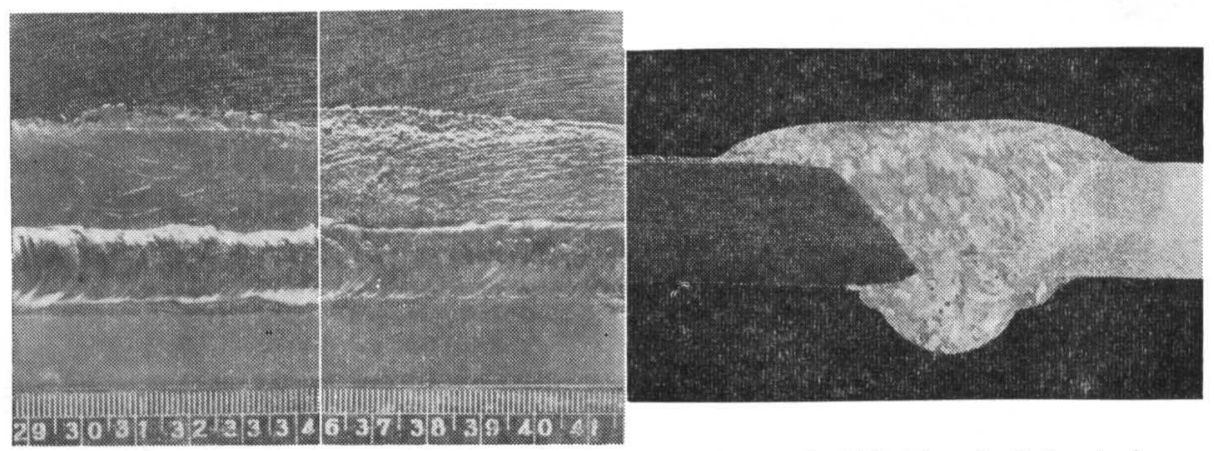

Photo. 3 Appearances of welds between 6061 alloy and $\mathrm{Al}(\mathrm{left}$ )-and $\mathrm{Zn}$ (center)coated mild steels, and typical cross-section of weld (right) 
Table 7 Mechanical properties of welds between mild steel and 3003-H 16 aluminum alloy

\begin{tabular}{|c|c|c|c|c|c|c|c|}
\hline $\begin{array}{c}\text { Specimen } \\
\text { number }\end{array}$ & Coating material & Joint design & $\begin{array}{c}\text { Pass } \\
\text { number }\end{array}$ & $\begin{array}{l}\text { Tensile strength, } \\
\text { kg/mm2 }\end{array}$ & $\begin{array}{l}\text { Yield strength, } \\
\text { kg/mm2 }\end{array}$ & $\mid \begin{array}{c}\text { Elongation } \\
\%\end{array}$ & Location of fracture \\
\hline $\begin{array}{l}1 \\
2 \\
3\end{array}$ & $\mathrm{~A} 1-5 \% \mathrm{Si}$ & Square & $\begin{array}{l}1 \\
2 \\
2\end{array}$ & $\begin{array}{l}11.0 \\
11.2 \\
11.6\end{array}$ & $\begin{array}{l}6.5 \\
7.5 \\
6.8\end{array}$ & $\begin{array}{l}13 \\
15 \\
16\end{array}$ & $\begin{array}{l}\text { Parent metal } \\
\text { Parent metal } \\
\text { Parent metal }\end{array}$ \\
\hline $\begin{array}{l}4 \\
5 \\
6 \\
7\end{array}$ & $\mathrm{~A} 1-0.6 \% \mathrm{Be}$ & Square & $\begin{array}{l}1 \\
1 \\
1 \\
2\end{array}$ & $\begin{array}{l}11.5 \\
13.2 \\
11.1 \\
13.5\end{array}$ & $\begin{array}{l}8.0 \\
8.9 \\
6.2 \\
9.6\end{array}$ & $\begin{array}{r}3 \\
11 \\
12 \\
4\end{array}$ & $\begin{array}{l}\text { Interface } \\
\text { Parent metal } \\
\text { Parent metal, bead } \\
\text { Interface }\end{array}$ \\
\hline $\begin{array}{r}8 \\
9 \\
10 \\
11\end{array}$ & $\mathrm{Al}-4.4 \% \mathrm{Cu}$ & Square & $\begin{array}{l}2 \\
2 \\
2 \\
2\end{array}$ & $\begin{array}{l}12.8 \\
12.0 \\
11.7 \\
12.6\end{array}$ & $\begin{array}{r}7.8 \\
7.4 \\
6.1 \\
7.8\end{array}$ & $\begin{array}{r}13 \\
5 \\
7 \\
15\end{array}$ & $\begin{array}{l}\text { Parent metal } \\
\text { Interface } \\
\text { Parent metal } \\
\text { Parent metal }\end{array}$ \\
\hline $\begin{array}{l}12 \\
13 \\
14\end{array}$ & $Z_{n}$ & $\begin{array}{c}\text { Single bevel } \\
\left(40^{\circ}\right)\end{array}$ & $\begin{array}{l}1 \\
1 \\
1\end{array}$ & $\begin{array}{l}13.5 \\
13.1 \\
11.5\end{array}$ & $\begin{array}{r}10.6 \\
9.2 \\
8.6 \\
\end{array}$ & $\begin{array}{l}7 \\
5 \\
8\end{array}$ & $\begin{array}{l}\text { Parent metal } \\
\text { Interface } \\
\text { Parent metal }\end{array}$ \\
\hline $\begin{array}{l}15 \\
16 \\
17 \\
18 \\
19 \\
20 \\
21 \\
22\end{array}$ & $\mathrm{Zn}-5 \% \mathrm{Al}$ & $\begin{array}{c}\text { Square } \\
\begin{array}{c}\text { Single bevel } \\
\left(40^{\circ}\right)\end{array}\end{array}$ & $\begin{array}{l}1 \\
1 \\
1 \\
1 \\
1 \\
2 \\
2 \\
2\end{array}$ & $\begin{array}{l}11.2 \\
11.5 \\
11.1 \\
10.7 \\
11.7 \\
12.5 \\
13.0 \\
12.9\end{array}$ & $\begin{array}{r}7.3 \\
- \\
7.9 \\
6.1 \\
8.5 \\
7.7 \\
7.7 \\
7.6\end{array}$ & $\begin{array}{r}12 \\
13 \\
3 \\
5 \\
3 \\
5 \\
12 \\
11\end{array}$ & $\begin{array}{l}\text { Parent metal } \\
\text { Parent metal } \\
\text { Interface } \\
\text { Interface } \\
\text { Interface } \\
\text { Bead, interface } \\
\text { Parent metal } \\
\text { Parent metal }\end{array}$ \\
\hline
\end{tabular}

Note 1) Mechanical properties were calculated on cross-sectional area of 3.2 mm thick material.

2) Filler rod : $2.4 \mathrm{~mm}$ dia. 4043 alloy

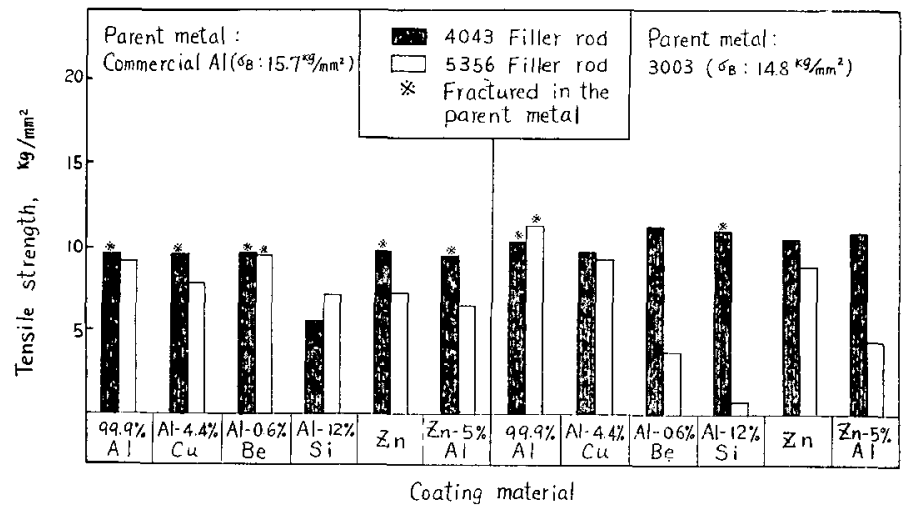

Fig. 1 Tensile strengths of welds (1)

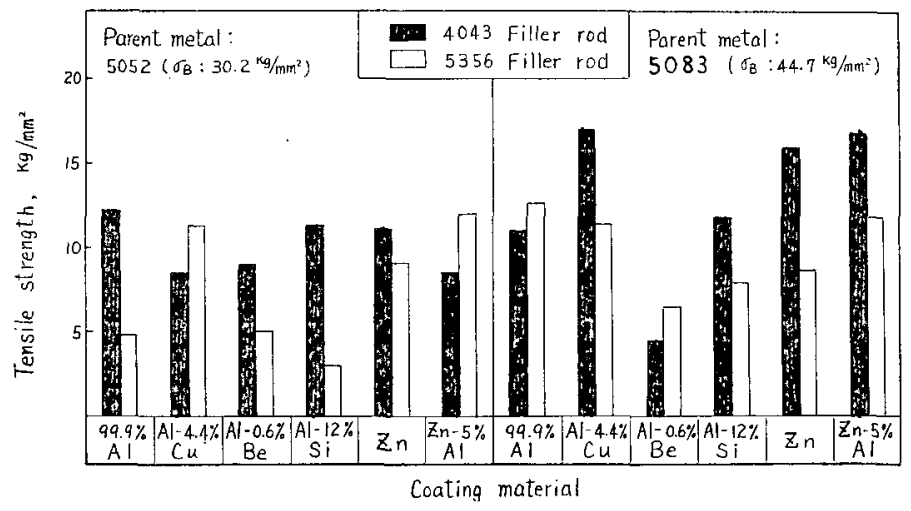

Fig. 2 Tensile strengths of welds (2) 
Tensile strength, $\mathrm{kg} / \mathrm{mm}^{2}$

11.6

11.5

9.8

12.2

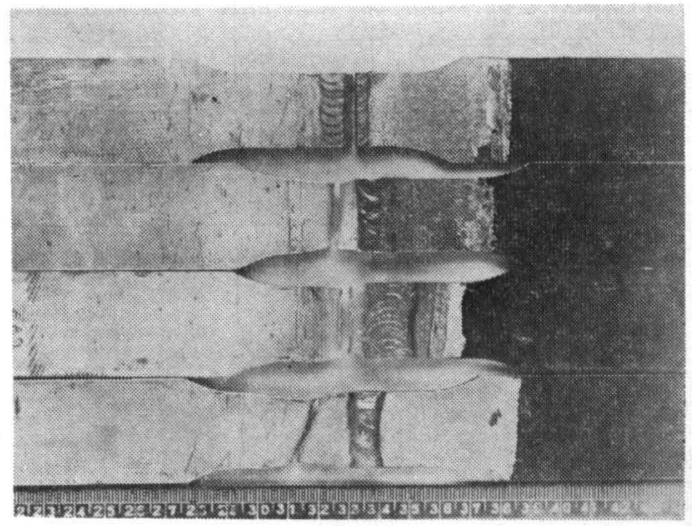

Al alloy Coating

$3003 \quad \mathrm{Al}-\mathbf{5} \% \mathrm{Si}$

$3003 \quad \mathrm{Zn}-5 \% \mathrm{Al}$

$1100 \mathrm{Zn}$

$3003 \quad \mathrm{Al}$

Photo. 4 Typical tensile specimens after tests (Filler rod : 4043)

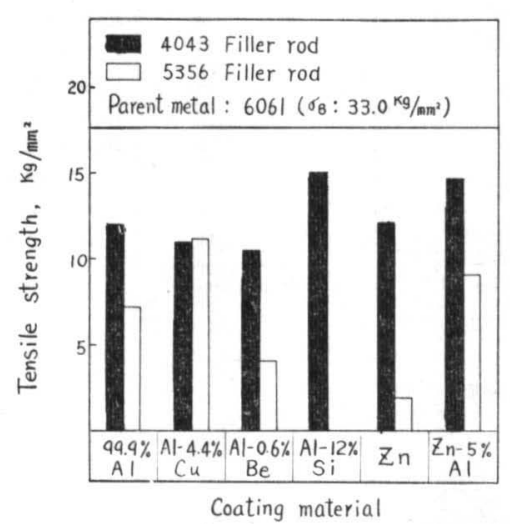

Fig. 3 Tensile strengths of welds (3)

一般にこの種の異種金属の溶接継手を加熱した場合に は, 境界を通じて異種金属相互の拡散が促進される結 果, 境界部の合金層が溶接のままの状態よりさらに成長 し, また鋼とアルミニウムの加熱による体積変化の相違 から，溶接部の機械的性質の低下が想像される，そこで $\mathrm{Zn}$ 被覆を行なった軟鋼板と 1100 材を 4043 溶加材によっ て溶接した継手について，試験片を $150^{\circ}, 250^{\circ}$ および $350^{\circ} \mathrm{C}$ の温度にてそれぞれ15日間連続的に加熱して溶接 部の機械的性質を調べた. なお試験には control specimen としてアルミニウム母材および溶接のままの試験 片を加えた。 その結果 $150^{\circ} \mathrm{C}$ にて 15 日間加熱した試験 片はアルミニウム側母材で切断したが, $350^{\circ} \mathrm{C}$ で15日間 加熱した試験片は溶接金属と軟鋼の境界部で切断した. 継手の機械的性質に及ぼす熱処理の影響を Fig. 4 に示 す. 熱処理後の継手の機械的性質は被覆材の種類すなわ ち境界部の合金層の性質によって当然異なるので, 種々 の被覆材を用いた継手に対して, さらに長時間加熱サイ クルを与えた実験を必要とするが，いずれにしてもこの 種の継手を高温で使用するのは適当でないと思われる.

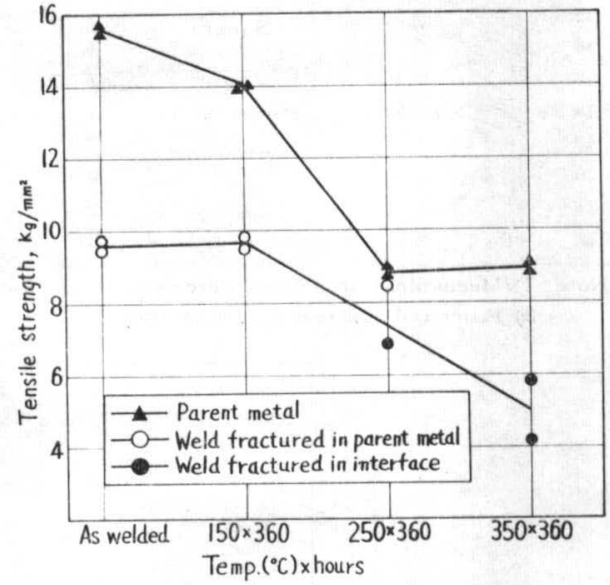

Fig. 4 Effect of heat treatment on the tensile strength of weld between comm. pure aluminum and $\mathrm{Zn}$-coated steel made with 4043 filler rod

しかしアルミニウム合金自体が高温ではほとんど用いら れないので, 従来アルミニウムが使用されている程度の 温度に対しては可能性があろう。

なお一部の突合せ継手に対して曲げ性を調べたところ では, 今回の実験範囲では, 余盛のついたままの試験片 を曲げると，溶接部中央で曲らないで，アルミニウム側 の熱影響部で曲げが生ずる試験片むあったが, 概して曲 げ性は良好でなかった。

(2) 管材の突合せ溶接部

Table 8 は外径 $22 \mathrm{~mm}$, 肉厚 $2 \mathrm{~mm}$ の 1100 (工業用 純アルミ）管と Zn を被覆した軟鋼管を，それぞれ 1260 および4043溶加材で溶接した場合の継手の引張および耐 圧試験の結果を示したあのである. 引張試験ではアルミ ニウム側で破断し，また耐圧試験ではアルミニウム管が 変形する程度の圧力に対しても溶接部が十分耐えうるこ 
Table 8 Mechanical properties of TIG-welded tube joints between commercial alu. minum and $\mathrm{Zn}$-coated mild steel made with 1260 and 4043 filler rods

(1) Tensile test

\begin{tabular}{c|c|c|c|c|c}
\hline $\begin{array}{c}\text { Specimen } \\
\text { no. }\end{array}$ & $\begin{array}{c}\text { Filler } \\
\text { rod }\end{array}$ & $\begin{array}{c}\text { Breaking } \\
\text { load, } \\
\text { kg }\end{array}$ & $\begin{array}{c}\text { Tensile } \\
\text { strength, } \\
\text { kg/mm² }\end{array}$ & $\begin{array}{c}\text { Elonga- } \\
\text { tion, } \\
\%\end{array}$ & $\begin{array}{c}\text { Location } \\
\text { of } \\
\text { fracture }\end{array}$ \\
\hline A & & 1015 & 8.0 & 27 & Al-tube \\
B & 1260 & 1030 & 8.1 & 18 & A1-tube \\
C & & 1070 & 8.5 & 12 & Al-tube \\
\hline 1 & & 1030 & 8.1 & 20 & A1-tube \\
2 & 4043 & 1030 & 8.1 & 17 & Al-tube \\
3 & & 1040 & 8.1 & 22 & Al-tube \\
\hline Al-tube & - & 1290 & 10.1 & 16 & - \\
\hline
\end{tabular}

(2) Pressure test

\begin{tabular}{c|c|c|c}
\hline $\begin{array}{c}\text { Specimen } \\
\text { no. }\end{array}$ & Filler rod & $\begin{array}{c}\text { Pressure, } \\
\mathbf{k g} / \mathrm{cm}^{2}\end{array}$ & Remarks \\
\hline D & 1260 & 120 & Inflated in Al-tube \\
E & 120 & 120 & Not inflated \\
\hline 4 & 4043 & 120 & \\
\hline 5 & & & \\
\hline
\end{tabular}

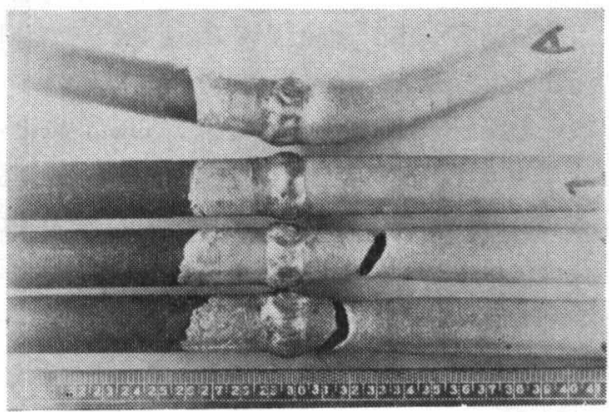

Photo. 5 TIG-welded tube joints between commercially pure aluminum and $\mathrm{Zn}$-coated mild steel made with 1260 and 4043 filler rods after presssure and tensile tests

とがわかった.

試験後の試験片の一例を Photo. 5 に示す.

\section{4 、結果に対する検討}

以上の結果からこの種の溶接法による継手に関して幾 つかの問題点があげられる.

\section{（1）溶接部強度のバラッキ}

溶接部強度のバラッキの原因としては, 先述のように 溶接に際してある程度の熟練を要するので, 溶接施工の 不慣れによるものの他に, 溶接前の軟鋼板の被覆処理が あげられ，とくに後者の影響が大きいものと考えられ る.今回の実験では, アルミニウムと軟鋼との溶接の可 能性を検討するための前提手段として, 実験室的な簡単 な装置および条件で被覆を行なったわけであるが, 一様

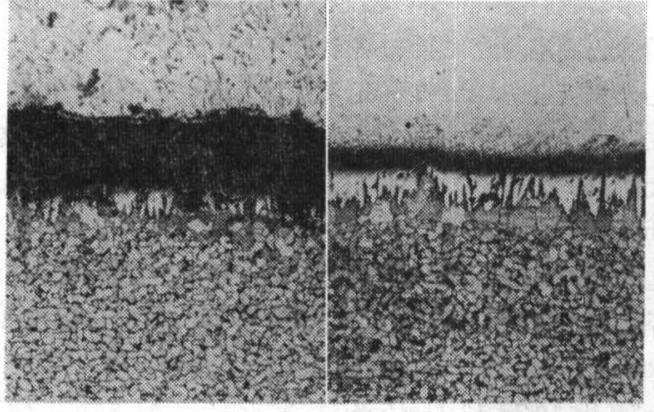

(1)

(2)

Photo. 6 Photomicrographs showing the interface regions fractured under the tensile load (taken from the weld between 6061 alloy and Alcoated mild steel made with 4043 filler rod $) \quad(\times 100) \times 4 / 5$

な溶接結果をうるためには，まず軟鋼側に健全な被覆を 行なうことが何よりあ大切である.しかし本実験によっ て, 軟鋼を適当に被覆すれば, TIG 法により軟鋼とア ルミニウムを接合しうるととが確認できた.

\section{(2) 金合層}

継手の機械的性質は軟鋼側が十分に被覆され，かつ溶 接技法も適当であるならば，溶接金属一合金層および合 金層一軟鋼のそれぞれの境界あるいは合金層そのあのの 性質によるものと思われる. そこで引張試験における切 断位置がこれらのどの部分に相当するかを顕微鏡により 調べてみた. その一例を Photo. 6 亿示す. 写真の試料 は $\mathrm{Al}$ で被覆した軟鋼板を6061合金と突合せ，4043溶加 材で溶接したあのであるが，切断は同一試料において， （1）では Al-Fe 合金層を通って，また（2）では合 金層之溶接金属の境界で生じているようにみられる、い っぼう溶接継手の引張試験結果によれば, 合金層の形成 に影響を与える各種の被覆材を用いても, 継手の引張強 さにほとんど差がないととから,引張強さは合金層その むのの成長の程度よりは, むしろ合金層と溶接金属の境 界の性質に影響されているとみなされる，しかしての点 については，今回の実験結果のみからはっきりした結論 は出されず，このためには軟鋼板に対して良質な被覆が なされていることを確認した上で，実験を行なう必要が ある.

\section{(3) 溶加材}

一般に $\mathrm{Al}-\mathrm{Mg}$ 系合金の溶接に $\mathrm{Al}-\mathrm{Si}$ 系の溶加材 を使用すると, 溶接金属中に $\mathrm{Mg}_{2} \mathrm{Si}$ が形成され, こ のために継手の延性が劣るので, 本実験では 4043 方 よび5356溶加材を用いてみたが, 使用したアルミニ ウム合金母材のすべてについて，概して4043溶加材の 
ほうがよい結果が得られた. Andrews ${ }^{3}$ は は Al-3.5\% Mg 合金と高温浸漬によりそれぞれ Sn および $\mathrm{Zn}$ を被覆 した鍋板とを，Al-5\% Si 溶加材で溶接した場合の継手 の引張強さは, 前者で 0.81 1.25 ton $/ \mathrm{in}^{2}$ (約 1.28 1.97 $\mathrm{kg} / \mathrm{mm}^{2}$ ), 後者で $0.93 \sim 0.97 \mathrm{ton} / \mathrm{in}^{2}$ (約 $1.46 \sim 1.53 \mathrm{~kg}$ / $\mathrm{mm}^{2}$ ), また高温浸清でそれぞれ $\mathrm{Al}$ および $\mathrm{Zn}$ を被覆 した鋼板と $\mathrm{Al}-3.5 \% \mathrm{Mg}$ 合金を $\mathrm{Al}-5 \% \mathrm{Mg}$ 溶加材で 溶接した場合の継手の引張強さは，前者で 11.2 13.2 ton $/ \mathrm{in}^{2}$ (約 $17.6 \sim 20.8 \mathrm{~kg} / \mathrm{mm}^{2}$ ), 後者で $6.8 \sim 8.4$ ton/ in $^{2}$ (約 $10.7 \sim 13.2 \mathrm{~kg} / \mathrm{mm}^{2}$ ) と報告し, Al-5\% Si 溶加 材による継手の引張強さが低いのは，形成された $\mathrm{Mg}_{2} \mathrm{Si}$ のためであるとしている．しかし本実験では $\mathrm{Zn}$ を被復 した軟鋼板を4043溶加材を用いて 5052 および 5083 合金 と溶接した場合の継手の引張強さはそれぞれ 11 および $16 \mathrm{~kg} / \mathrm{mm}^{2}$ であって，いずれも5356溶加材による溶接 部より高い值を示した.

作業性の点加らは5356より4043溶加材のほうがすぐれ ているようにみられたので，とくに Al-Mg 系合金と軟 鋼との溶接に抢いては，溶接金属中の $\mathrm{Mg}_{2} \mathrm{Si}$ ，作業性に 基づく溶接部の欠陷あるいは合金層の成長に与える溶加 材の影響などと継手の機械的性質との関連において，適 当な溶加材を選定する必要があるう。

\section{（4）溶接ビードの形状}

継手の強度が低い試験片は概して溶接金属之鋼板との 接合面積が小さく、したがってこの種の溶接法において は，溶接金属と鋼板との接触面積を大きくするように， 一般の溶接法より溶接部の表面执上び裏面とも余盛の幅 を広く溶接するほうがよいと思われる。

\section{(5) 溶接層数}

溶接層数が $1 \sim 2$ 層では層数の増加による継手の機械 的性質の低下が認められなかったが，さらに層数を必要 とするような用途に対しては，層数が境界部の合金層に 与える影響についても調べる必要があるう.

\section{5. 結論}

高温浸漬法によって各種の被徣材を軟鋼に施てした後 で，TIG 法により軟鋼とアルミニウム合金を溶接する 方法について検討した結果，つぎのような結論が得られ た.

（1）被覆材については $\mathrm{Al}$ にそれぞれ $\mathrm{Si}, \mathrm{Be}$ およ び $\mathrm{Cu}$ を添加すれば， $\mathrm{Al}-\mathrm{Fe}$ 金属間化合物の成長が抑 制され， $\mathrm{Mg}$ および $\mathrm{Ag}$ の添加はその効果がなかった。 また $\mathrm{Zn}$ および $\mathrm{Zn}-5 \% \mathrm{Al}$ を被覆した場合には，ほ上 んど合金層が認められない。
（2）溶接部の強度はアルミニウム側母材が1100およ び3003合金では，引張試験において母材で切断する程度 であったが，5052，5083および6061合金では母材の強度 に至らなかった。

（3）溶接部の強度は高温での長時間加熱によって低 下するので，乙の種の継手を高温で使用するととはでき ないが，アルミニウムが使用されている程度の温度に対 しては可能性がある.

（4） Al-Fe 金属間化合物層が溶接 部の強度に影響 すると思われたので，種々の被覆材を用いたが，今回の 䒠験で被㠅材の鋫類と継手の強度との問にはっきりし た傾向が認められなかった．合金層と溶接部の機械的性 質との関係については，趾全な被覆を有する試料につい てさらに検討が必要である.

（5）溶加材は概して5356より4043溶加材のほうが結 果がよかった。

（6）溶接にはとくにアークスタート時に被覆を溶融 はく離させないように注意する必要があり，一たん被覆 が溶融はく離すると，その後の溶接の継続が不可能であ る。また溶融はく離の傾向は被覆の種類によっても若干 異なるようである。

（7）軟銅板を適当に被覆すれば，TIG 法化よって 軟鋼とアルミニウムの接合が可能であるととを確認し た。しかし，溶接部の機械的性質は主として被覆の良否 および溶接技法の熟練の程度によってほぼ決定されるの で，て扎らの点に注意してさらに実験が必要である.

\section{参考 文 献}

1) M.A. Miller and E.W. Mason, "Properties of Arc. Welded Joints between Aluminum and Stainless Steel", W.J., Vol. 35 (1956), No. 7, 323 s-328 s.

2) L.A. Cook and M.F. Stavish, "Welding Aluminum to Copper Using Inert-Gas Metal-Arc Process", Ibid, Vol. 35 (1956), No. 4, 348-355.

3) D.R. Andrews, "Joining Aluminium to Mild Steel by Argonarc Welding", British W.J., Vol. 9 (1962), No. $12,650-658$.

4) P.T. Stroup and G.A. Purdy, "Aluminum Coating of Steel-A Comparison of Various Processes", Metal Progr., Vol. 57 (1950), No. 1, 59-63, 128, 130.

5) T. Heumann und S. Dittrich, “Über die Kinetik der Reaktion von festem und flussigem Aluminium mit Eisen”, Z. Metallk., Bd. 50 (1959), H. 10, 617-625.

6) K.G. Coburn, "Aluminised Steel-Its Properties and Uses", Metallurgia, Vol. 60 (1959), No. 357, 17-20.

7) M.L. Hughes, "Hot-Dip Aluminised Steel-Its Preparation, Properties and Uses", Sheet Metal Ind., Vol. 33 (1956), No. 346, 87-98.

8) D.M. Dovey and A. Waluski, "Continuous Dip Alt1minising of Steel", Metallurgia, Vol. 67 (1963), No. $403,211-217$. 